\title{
Verbal Expression in the Pilgrimage Tradition of the Suntenjaya Village Community
}

\author{
Muhammad Rifqi Fauzan Arifin ${ }^{1 *}$, Wakit Abdullah Rais ${ }^{1}$, Henry Yustanto ${ }^{1}$ \\ ${ }^{1}$ Department of Program of Linguistics Faculty of Cultural Sciences, Universitas Sebelas Maret, Surakarta 57126, Indonesia
}

Article History
Received: 14.09 .2021
Accepted: 23.10 .2021
Published: 19.01 .2022
Journal homepage:
https://www.easpublisher.com
Quick Response Code

\begin{abstract}
This study seeks to find the meaning behind verbal expressions in the pilgrimage tradition of the people of Suntenjaya Village, Lembang District, West Bandung Regency, and West Java Province, Indonesia. This study focuses on the cultural meanings contained in verbal expressions in the form of words, phrases, clauses, and discourses contained in the pilgrimage tradition of the Suntenjaya Village community. The method used in this study is a qualitative descriptive method using an ethnoscience modeled analysis with an ethnolinguistic paradigm. The data in this study refers to verbal and nonverbal expressions contained in the pilgrimage tradition of the Suntenjaya Village community. The source of data in this study is the people of Suntenjaya Village who carry out and preserve the pilgrimage tradition. The data collection method in this study used the listening method and the conversational method with notetaking techniques and in-depth interview techniques. This study found 3 categories of verbal expression, namely doa, the pronunciation of ijab kobul, and the pronunciation of ngukus.
\end{abstract}

Keywords: Ethnolinguistics, pilgrimage, anthropological linguistics, Suntenjaya.

Copyright (C) 2022 The Author(s): This is an open-access article distributed under the terms of the Creative Commons Attribution 4.0 International License (CC BY-NC 4.0) which permits unrestricted use, distribution, and reproduction in any medium for non-commercial use provided the original author and source are credited.

\section{INTRODUCTION}

Pilgrimage activities are often found in our lives. This is seen as something that is generally done by the society in the world. There are various motivations behind its implementation. One of the interesting motivations to study is a pilgrimage as a medium for conveying the values of life by the ancestors of a society. This is found in the pilgrimage tradition of the Suntenjaya Village community.

The people of Suntenjaya Village use pilgrimage as a medium to preserve and teach the values they uphold. In general, these values are seen as a culture of the Suntenjaya Village community which is manifested in an activity that has been carried out from generation to generation. Goodenough (Garvin P. L. (eds), 1957: 167) views culture as something that a person needs to know and believe to behave properly and correctly to be accepted and be able to play a role following roles that can be accepted by community members in ways that have been agreed upon by the community. In this case, the people of Suntenjaya Village use the pilgrimage tradition to teach and preserve ways to live so that their descendants can behave properly and correctly so that they can be accepted in social life. These values are represented through verbal expressions contained in the pilgrimage tradition of the Suntenjaya Village community. Verbal expressions refer to words, phrases, clauses, discourses, and other lingual units found in the pilgrimage tradition of the Suntenjaya Village community. Through the ethnolinguistic paradigm with ethnoscience modeled analysis, it is understood that it can reveal and explore the cultural values contained in verbal expressions in the pilgrimage tradition of the Suntenjaya Village community.

Harimurti (1982:42) views that ethnolinguistics is a branch of linguistics that investigates the relationship between language and rural communities or people who do not yet have writing. This view stems from the literature available at that time where the study of language and culture at the same time is still rarely found in Indonesia. Furthermore, Riley (2007:8-9) states that ethnolinguistics is an approach that sees language as a medium for studying the life experiences of a community group and is a science that explores the relationship between language and culture in a social society simultaneously. He compares ethnolinguistics with sociolinguistics which sees language as a social 
institution of a society that is different from ethnolinguistics which sees language as a manifestation of the culture of a society. In line with that, Foley (1997:3) considers ethnolinguistics to be a branch of the field of linguistics that places language broadly in its social and cultural context in shaping and maintaining social structures and cultural practices. Ethnolinguistics is also said to be an interpretive science that explores language to find understanding behind a culture by looking at language through the anthropological and cultural core prism behind its use, abuse, and also through language that is no longer used from various forms, registers, and style (Chapelle eds., 2013:113).

On the other hand, Spradley (2007: xii) states that ethnoscience begins developed in the 1960s and has several other names such as cognitive anthropology or new ethnography. Ethnography itself is based on the assumption that knowledge of all cultures is of great value. Furthermore, Ahimsa-Putra (2003: 34-45) also states that ethnoscience or new ethnography is the knowledge possessed by a nation, more precisely, certain ethnic groups or social groups. Before its emergence, ethnolinguistic research tended to using modern ethnographic models (1915-1925). According to Spradley (2007: xii) ethnoscience is a method for exploring and extracting cultural knowledge of a society contained in his mind through the language they uses. Ethnoscience today is often also labeled with the terms new ethnography, and cognitive anthropology (Abdullah, 2017).

Several similar studies use the ethnolinguistic paradigm with an ethnoscience analysis model, including: (1) Research documented through an article entitled Lingual Unit for Disclosure of Local Wisdom in Environmental Preservation written by Mardikantoro (2016) focuses on Javanese lingual units as representations of local wisdom of the Samin community in protecting the environment in Blora Regency. He found that lingual units which are divided into words, phrases, sentences, and discourses have the value of local wisdom of the Samin community. Words that have local wisdom values can be seen in the words disusruk, disesek/diret, diarit, and dibedhol; (2) research documented through an article entitled Local Wisdom of the Javanese Language in the Tingkeban Tradition in Laweyan Village, Surakarta Municipality An Ethnolinguistic Study written by Nurnaningsih (2019). He focuses on verbal and non-verbal expressions in the traditional tingkeban/mitoni ceremony as a form of local wisdom of the Javanese community, especially the people of the Laweyan village of Surakarta; (3) research documented through an article entitled Verbal and Non-Verbal in the Javanese Language of the Coastal Community in Banjar Kemuning Village, Sidoarjo written by Chafidi et al. (2019) focusing on verbal and nonverbal expressions in coastal communities of Banjar Kemuning, Sidoarjo; and (4) research documented through an article entitled
Local Wisdom of the Fishermen's Language and Livelihood traditions in the Southern Coast of Kebumen, Central Java, Indonesia (An Ethnolinguistic Study) conducted by Abdullah (2015) focusing on local wisdom in language and culture Kebumen fishing community. All of the above studies have succeeded in uncovering the cultural meaning behind verbal expressions used by society through an ethnolinguistic paradigm with an ethnoscience analysis model. But the studies above have not revealed the cultural meaning contained in the pilgrimage tradition in general and specifically in the pilgrimage tradition of the Suntenjaya Village community. Based on this, the researchers conducted similar research with different study objects.

Contextually the verbal expression contained in the pilgrimage tradition of the Suntenjaya Village community is a speech that is taught from generation to generation based on the guidance of their ancestors. This study found several categories of verbal expression, namely prayer, consent kobul, and steaming. In addition, the verbal expression is an expression made based on the understanding of each member of the Suntenjaya Village community towards the teachings of their ancestors and the teachings of their belief, namely Islam. Thus, there are differences in the forms of verbal expression found in this study but not with the meanings they contain. This will be discussed in the next result and discussion section.

\section{METHODS}

This type of research is qualitative which is seen as a means to understand the phenomena experienced by a society in a particular context that is holistic and described descriptively in the form of words through language by utilizing natural methods (Moleong, 2007:6). Technically, the data obtained by the researcher was obtained using the listening technique. According to (Sudaryanto, 2015:203), the listening method is a method used by researchers by listening to the use of language with informants as users.

The method is carried out simultaneously using basic techniques in the form of tapping techniques followed by advanced techniques, namely the listening and speaking techniques. The listening-engagement technique is another term for the participatory observation technique because researchers are required to be directly involved in dialogue with the community. Technically, this technique can be understood as a researcher's effort by entering a situation where he actively acts and acts as a member or participant in cultural activity as well as an observer who observes a cultural phenomenon as data (Abdullah, 2017: 70).

Furthermore, the researcher used the speaking method. Sudaryanto (2015: 208) states that the proficient method is a method in which there is contact 
between researchers and informants as resource persons, which in practice is directly proportional to the interview method. Technically, the proficient method is carried out with the help of basic fishing techniques and advanced face-to-face techniques, which is a method that attracts informants to provide answers as data by providing pre-arranged questions orally and face to face or direct interviews with informants at the location. Study. The type of interview chosen by the researcher in this study is in-depth interviewing; this is because the researcher needs the depth of information provided by the informant regarding the pilgrimage tradition of the Suntenjaya Village community in addition to collecting as much information as possible.

In the process, the researcher uses the support of (1) recording devices in the form of devices that can record audio and video to facilitate the implementation of advanced techniques in the form of recording techniques to minimize data loss and (2) writing instruments consisting of notebooks and pens to support the selected note-taking technique. to collect information that is considered important and necessary in the form of verbal and nonverbal expressions in the pilgrimage tradition of the Suntenjaya Village community to be explored by researchers when conducting subsequent interviews and for later analysis.

Researchers in using ethnoscience analysis follow the directions given by Spradley (2007: 63-312) which he calls the Developmental Research Sequence which consists of 12 stages, namely: (1) the researcher determines the informants to be interviewed; (2) researchers interviewed informants; (3) the researcher makes ethnographic notes; (4) the researcher in the interview asks descriptive questions; (5) then the researchers conducted an ethnographic interview analysis; (6) make a domain analysis; (7) ask structural questions; (8) researchers conducted taxonomic analysis; (9) ask contrasting questions; (10) analyze the components of meaning; (11) find cultural themes; and finally (12) wrote an ethnography of the people of Suntenjaya Village on their pilgrimage.

In this study, researchers used a phenomenological thinking strategy. Moleong (2007:15) states that the phenomenological thinking strategy is a thinking view that focuses and emphasizes worldly interpretations based on human subjective experiences. Interpretation is an attempt to describe a culture using language as a medium to understand the meaning of phenomena, events, and their relation to the society being studied based on the context of life in the actual situation (Subroto, 2007:6). Thus, it can be said that this effort is an attempt to enter into the mind of the informant to find and understand the concept of the world that lies behind it and is used to survive and develop his life.

\section{RESULTS AND DISCUSSION}

In this study, it was found that verbal and nonverbal expressions were divided into several categories in the pilgrimage tradition of the Suntenjaya Village community. In the verbal expressions found in the pilgrimage tradition of the Suntejaya Village community which consists of: (1) doa, the Suntenjaya Village community perceives doa as an activity of reading the holy verses of the Koran; (2) ijab kobul, in this case, the people of Suntenjaya Village perceive contextually in the pilgrimage tradition as a speech in which there is a statement to express requests, expectations, praise, and goals in carrying out pilgrimage activities; and (3) steaming, which is seen by the people of Suntenjaya Village as an activity of whispering doa and ijab kobul in the previous two categories to incense in the form of small grains that have been wrapped in a piece of paper and then stored on the coals of fire contained in the oven. In a container made of clay.

\section{DiSCUSSION}

The reading of prayers in the tradition of the zairah community of Suntenjaya Village is perceived as an activity of reading the holy verses of the Koran which includes the reading of Surah Al-Fatihah verse 17, Surah Al-Baqarah verse 1-5, Surah Al-Baqarah verse 163, Sura Al-Baqoroh verse 255, Surah Al-Baqoroh verse 284-286, Surah Al-Ikhlas verse 1-4, Surah AlFalaq verse 1-5, Surah An-Nas verse 1-7, Surah Taha verse 25-28, Surah Hud verse 73, Surah Al-Ahzab verse 33, Surah Al-Ahzab verse 56, Surah Ali-Imron verse 173, Surah Ali-Imron verse 102, Surah Al-Anfal verse 40, Surah Yasiin verse 1-83, and Surah Ibrahim verse 7. Contextually the reading of the holy verses of the Koran is an effort that is believed by the people of Suntenjaya Village so that they are always close to their God because all the people of Suntenjaya Village embrace Islam. In addition, the reading of the Holy Quran is seen as an affirmation by the people of Suntenjaya Village so that they are always protected by God and are not kept away from His pleasure. The belief that reading the holy verses of the Koran can make them protected by God and get His blessing is a value or knowledge that is taught from generation to generation by their ancestors other than the result of their understanding after understanding the contents of the holy verses of the Koran. Mentioned In other words, this belief is a synthesis between the teachings of their ancestors and their understanding of the holy verses of the Koran which shows a tacit cultural phenomenon that refers to the obedience and desire to preserve culture by the people of Suntenjaya Village based on the culture of their ancestors.

Furthermore, verbal expressions in the category of ijab kobul which are perceived contextually by the people of Suntenjaya Village in the pilgrimage tradition as a speech in which there are statements to 
express requests, expectations, praise, and goals in carrying out these activities tacitly showing concern and obedience to the teachings of their ancestors. . It is necessary to understand beforehand that Ijab Kobul is a speech that is taught from generation to generation by the ancestors of the Suntenjaya Village community. Technically it can be explained that the ancestors of the Suntenjaya Village community taught the core values in the form of values or things contained in the kobul ijab. The following forms of kobul consent are found in the pilgrimage procession of the Suntenjaya village community.

"Bismilahirohmanirahim. Asalamualaikum. Sim abdi seja ngadeuheus ka Gusti nu maha Suci ka Nur Muhammad, nu ngadamel bumi-langit, Sawarga sareng Naraka $\mathrm{Nu}$ ngadamel alam sareng Sapangeusina. $\mathrm{Ka} \mathrm{Nu}$ nanggeuy Cahaya Beurang Peuting Nu nanggeuy Cahaya bumi, Cahaya langit, Cahaya cai, Cahaya angin, Cahaya geni, Cahaya johar. Ka Ibu Hawa Rama Adam, kanu ngadamel poe 7, dawuh 5, bulan 12, taun 8, alip 1, windu 2. Ka Ibu ka Rama, ka Sunan Ambu Sunan Rama ka Saderek opat ka lima pancer ka dulur anu 7, ka Malaikat Jabaniah. Ka per wali per Nabi para mumin para malaikat para aulia para sahabat. Agungna ka Gusti Rasul Jembarna ka para Karamat chususna ka ... Oge ka Kakang seda Rasa ka adi Seda Sakti, ka sang Bujira sang geleber herang. Bade nyanggakeun pangabakti Sangu sapulukaneun sareng Rujak suci sucining pangerang. Sakedik nu disanggakeun ageung nu disuhunkeun. Bismilah bakalning Allah sang intel putih bakal manusa, sang gerentel putih bakalining menyan, sang lemes putih bakalning haseup, Pangeran raja, geseng namaning seuneu. Kaula pangnyeuneukeun ka $\mathrm{Nu}$ Agung, pangdongkapkeun $\mathrm{ka} \mathrm{Nu}$ Kawasa, pangnepikeun kanu pasti ku Haseup Kukus Nyimas pohaci Wiwitan dana namaning menyan. Heuncir kuning cendana rasa kaula ngebong menyan seja ngahaturi kang bangung mikeun sadaya."

(I intend to draw closer to God the Most Holy to the light of Muhammad, who created the earth-sky, heaven, and hell who created nature and all its contents. To those who watched the light of day and night, who watched the rays of the earth, the rays of the sky, the rays of water, the rays of the wind, rays of fire, rays of gems. To Mother Eve, Father Adam, to those who created day 7 , time 5, month 12 , year 8 , alif 1 . To Mother to Father, to Queen Mother to King Father to brothers four to five pillars to brothers the seventh, to the guardian angels of hell. To the beloved, namely the Prophet, the believers, the angels, the aulia, the companions. The glory is to Rasul in general to the saints, especially to ... Then to Kakang Seda Rasa to Adi Seda Sakti, to Sang Bujira Sang Geleber Herang. I want to give a small amount of Sangu along with the holy Rujak, the holy prince. A little is given as much as is asked. In the name of Allah who all comes from Allah, sang intel putih of human origin, sang gerentel putih from frankincense, the smooth white is the source of smoke, Prince Raja, black is burning called fire. I ask to be burned to the Supreme, please convey to the Almighty, please deliver it to the sure through Haseup Kukus Nyimas Pohaci Wiwitan and his name is incensed. The sandalwood yellow rings I taste burn incense to surrender everything to Him.)

"Bismillah. Asalamaualaikum. Sahadat. Salawat. Istigfar. Lahaola. Simkuring seja pangabakti ka gusti nu maha suci kapara malaikatna oge ka para nabi sareng rosulna gusti anu tos nyiptakeun alam mayapada sareng sa eusina kanggo kahirupan umatna. Teu kalangkung ka ibu anu ngandung ka rama anu ngayuga, indung tunggul rahayu bapa tangkal darajat moal aya pangampura gusti upami abdi teu di hampura ku indung sareng bapa. Oge teu hilap ka dulur anu opat ka lima pancer nyaeta acining, bumi, cai, angin, sene nu aya dina badan urang. Mudah-mudahan aya rido gusti. Oge ka nyimas sri dangdayang trisnawati oge kanu kasep Raden Bagus Sarana, anu alor di kuyakkeyekna di beureum di hideungan nyuhunkeun karidoana. Saunda maning menyan acining umat sirtik sir peletek nyimas pohaci geni niymas pohaci sekarwangi pang dugikeun sakumaha pamasadan anu... Ka gusti nu maha suci pamudah mudahan di kobul ku gusti. Kunpayakun.”

(In the name of Allah. May salvation be with you. The creed. Salawat. Asking forgiveness from Allah. Everything is for Allah. I intend to do this to Allah the Most Holy to His angels as well as to His Prophets and Messengers, the Lord who has created all nature and all its contents for the life of its people. Not to be missed by the mother who is pregnant with the father who provides for it, the mother of Tunggul Rahayu, the father of Tangkal Darajat, there will be no forgiveness from God if I am not forgiven by Mother and Father. the essence of the earth, water, wind, fire that is in our bodies. May God bless. Also to nyimas sri dangdayang trisnawati as well as to the beautiful Raden Bagus Sarana, who can't stand being wrinkled, reddened, blackened, asking for his pleasure. nyimas pohaci geni nyimas pohaci sekawangi please convey as intended, namely... To the holiest may God grant it. So so be it.)

"Nyanggakeun sangu putih sapurulukaneun ka ibu ka rama nyanggakeun babakti abdi rurujakan, minyak, sisir, eunteung, lembareun, sesepeun, ka ibu ka rama ka Nu Nangtayunan siang kalawan wengi ka badan abdi ieu abdi landong ka susah ka beubeurat hayang dipangmukakeun hayang dijaring diaping diriksa siang kalawan wenginan ku Gusti Allah nu maha suci teh sing yakin abdi ka Gusti teh ieu nyuhungkeun ditulung ka Gusti. Al-Fatihah, Robighfirli Aamiin."

(Giving a little white sangu to mother to father, handing over my good deeds, rujak-rujakan, oil, comb, 
mirror, materials for nyeupah, cigarettes, to mother to father to the One who overshadows day and night to me. I want to be guarded, guided, and cared for day and night by the Almighty God, I'm sure I only ask God for help from Al-Fatihah, robigfirli Amen.)

Based on the verbal expression above, it can be understood that the people of Suntenjaya Village ask only their God. In this case, God is seen as a being that holds everything. The people of Suntenjaya Village believe that there is a core element in every creature. They call the core element with the term light. In the verbal expression of the kobul consent, the phrases of Cahaya Bumi 'ray of the earth', Cahaya lanigt 'ray of the sky', Cahaya cai 'ray of water', Cahaya angin 'ray of wind', Cahaya geni 'ray of fire', and Cahaya johar 'ray of gems' were found. Cahaya 'ray' in this case is understood to be a word with a connotative meaning that refers to an element or essence in an object or element. The essence is seen as an essence that can maintain or revive the medium. In other words, the people of Suntenjaya Village see that every object on earth can bring up dialectics for other objects, both for objects contained in these objects and outside these objects. For example, the earth in this case is an object in which there is life, that life can be realized with the help of sunlight which then gives rise to life in it such as plants, animals, humans, and others. In addition, plants, animals, and humans can absorb sunlight and other objects such as water, wind, and fire that affect their lives or vice versa. In this phenomenon, there is a causal event that afflicts living things due to their relationship with inanimate objects. The incident is seen by them as an event that arises not solely because of the ability of the essence but a form of the majesty of God. This is evidenced by the expression saderek opat ka lima pancer 'brothers four and origins five' which means the core elements contained within us and we are part of them. Saderek opat 'fourth brother' in this case refers to the core elements that make up and exist within us, namely the elements of earth, water, wind, and fire. Earth, which refers to the basic material humans were created, namely soil. They believe in God's word which states that humans were created by God from clay. Furthermore, water refers to the liquid blood which is believed to be a substance that has an important role in their lives. Wind, in this case, refers to the human mind which is invisible, besides that the human mind is seen as a wind that can move quickly and is invisible. And fire refers to human desires that will benefit if controlled properly and will be a disaster if not controlled properly. The four essences are gathered in one pancer 'origin', namely humans who submit to their God. In other words, man as a being who is conceived by his Lord, in which there are four elements, should be submissive and glorify his god. In addition, this expression shows that the people of Suntenjaya Village believe that God controls everything that is inside and outside of them. In this case, God arranged him so that he could be born and live on earth through his parents. This phenomenon applies to Nabi Adam AS, meaning that Prophet Adam AS and Siti Hawa have descendants and continue to have descendants until they reach the people of Suntenjaya Village through their ancestors. This is what makes the people of Suntenjaya Village respect their ancestors. In simple terms, it can be said that the people of Suntenjaya Village are descendants of Prophet Adam AS as well as his ancestors. This is shown by verbal expressions that show respect to Ibu Hawa Rama Adam 'to Mother Eve, Father Adam' and to Sunan Ambu Sunan Rama 'Queen Mother to King Father' and Ibu ka Rama 'to Mother to Father'. This expression shows that the people of Suntenjaya Village respect their ancestors because they see the majesty of their God through this phenomenon. Ibu Hawa Rama Adam refers to the first humans who lived on earth because of which they could be born on this earth. In this case, they see that there is majesty of God from the phenomenon of the Prophet Adam AS and Siti Hawa which only from a pair of humans can breed up to billions of other humans including the Suntenjaya Village community and their ancestors. In addition, if it wasn't for their ancestors who gave their knowledge, it would not be possible for them to know the information, this also applies to their parents, namely if their grandfather or the mother and father of their current parents do not tell the information then they will never be able to provide information. this information to their children, and continues to their lord, namely the Messenger of Allah, without the Messenger of Allah who received revelations and conveyed messages from their Lord they would never know the information. This is what makes the people of Suntenjaya Village very respectful and uphold the Prophet Muhammad. This is reinforced by the expression kanu ngadamel poe 7, dawuh 5, bulan 12, taun 8, alip 1, windu 2 'to those who created day 7, time 5 , month 12 , year 8 , alif 1 , windu 2' which shows the order of time in their life. In other words, the expression shows an implied command to look back to find out who their ancestors were in addition to showing who created that time. The one who created the time is understood as God which is indicated by alip 1 'alif 1', namely the Almighty God.

Furthermore, they respect their fellow Muslims who have already left this world. This was expressed with ka Kakang seda Rasa ka Adi seda Sakti 'to Kakang seda Rasa to Adi seda Sakti'. The expression refers to older and younger fellow Muslims who have left this world before whom they do not recognize but pray for. This expression shows that they have great respect for their fellow human beings, even someone who has died and they don't know even though they pray.

Furthermore, the people of Suntenjaya Village believe that there is someone who has a higher degree than him. In this case, the degree indicates the closeness of a person to his God who is considered to have the ability to deliver prayers to his God until the prayer is 
heard or accepted. This is found in the expression $k a$ per wali per Prophet, para mumin, para angels, para aulia, para sahabat 'to the beloved of Allah, namely the prophet, the believers, the angels, the saints, the companions', in this case, they pray for their prophet, namely the Messenger of Allah, the believers, namely the people. Who believe in Allah, to the angels who always worship Allah, the saints, namely those who are close to Allah, and to the companions of the Messenger of Allah who has been glorified by Allah and His Messenger? They believe that for their prayers to be heard by Allah they are required to pray to the Prophet Muhammad and pray for the believers and those who are honored by Allah and His angels. This also shows that the people of Suntenjaya Village are individuals who are obedient to God's commands.

The people of Suntenjaya Village realize that they are servants of their God, with that awareness they use euphemisms in asking their God. It also shows things that are considered sensitive in their view. Every living thing needs food for its survival, including humans, including the people of Suntenjaya Village who need rice as their staple food which can then be processed into rice or porridge and others. During the colonial period, rice was considered a special food, and not all the people of Suntenjaya Village could reach it. So they asked their Lord to give them rice so they could process it into rice. With their awareness that rice is a special item and they feel reluctant to express it openly to their God, they use the phrase nyimas sri dangdayang trisnawati which means rice to ask their God. A phrase is a form of euphemism from the word rice which is considered sensitive. In addition, they believe that through rice that is processed into rice which then provides a source of energy to them, then with the energy produced they can try to find money as a medium of exchange so that they can meet their daily needs. It can be understood that the expression of Kasep Kasep Raden Bagus Sarana 'to the beautiful Raden Bagus Sarana' is a form of euphemism for the word money that is offered to his God. This expression shows that money is something that is considered sensitive by the people of Suntenjaya Village. Based on this explanation, it can be understood that the expressions of oge ka nyimas sri dangdayang trisnawati oge kanu kasep Raden Bagus Sarana, anu alor in kuyak-keyekna in beureum in hideungan nyuhunkeun karidoana are 'also to Nyimas Sri Dangdayang Trisnawati as well as to the strong, beautiful Raden Bagus Sarana crumpled, reddened, blackened asking for his pleasure' means that they as weak creatures ask for humility from their Lord to be given a source of energy in the form of rice from which they can earn a living in the form of money so that they can meet the daily needs of themselves and their families. Thus, it can be understood that the phrase Nyimas Sri Dangdayang Trisnawati and Raden Bagus Sarana is not a supernatural figure or personification but a form of euphemism that shows that in fact, the people of Suntenjaya Village are weak creatures without the help of their almighty God. In addition, this expression shows that the people of Suntenjaya Village believe that there is an intermediary between God's will and himself. Based on this, they have the belief that everything that happens to them is a form of God's love through everything that happens to them as an intermediary. Next, the expression of Kaula pangnyeuneukeun ka Nu Agung, pangdongkapkeun ka Nu Kawasa, pangnepikeun kanu pasti ku Haseup Kukus Nyimas pohaci Wiwitan dana namaning menyan. Heuncir kuning cendana rasa kaula ngebong menyan seja ngahaturi kang bangung mikeun sadaya 'I ask to be burned to the Supreme, please convey it to the Almighty, please send it to the sure through Haseup Kukus Nyimas Pohaci Wiwitan and his name is incense. Henci kuning cendana rasa I burn incense to surrender everything to Him shows the belief that there is an intermediary between the people of Suntenjaya Village and their God. The expression in the form of the phrase Haseup Kukus Nyimas pohaci refers to the smoke produced by burning gerentel putih or incense as an intermediary for the prayers they had previously said. They see that they need a tool or media that can convey their prayers to their Lord, in this case, they use the smoke produced from burning incense or ngukus as a conveying tool or medium. This is because they assume that the smoke disappears following the air which generally moves upwards which from this movement they believe that their prayers also disappear into other realms that are above them. Furthermore, because the smoke smells good or smells good which they call the expression niymas pohaci sekarwangi they believe that the aroma shows an attitude of respect for their Lord. In addition, they use fire as a tool or medium to deliver their prayers. They use the expression nyimas pohaci geni which means fire through which they can produce smoke as a means to deliver their prayers to their Lord. This is shown by the expression Wiwitan dana namaning menyan 'origin of the fund named incense' which means that they see a dana 'fund ' or Wiwitan power or kawitan which means origin or comes from namaning 'namanya' which means its origin is from menyan 'incense'. In other words, they see that frankincense is a force that can deliver their prayers to their Lord so that their prayers can be heard or answered by their Lord.

Another verbal expression found in the pilgrimage tradition of the Suntenjaya Village community is ngukus. As previously explained, steaming is a procession of burning incense in a container that is generally made of clay. The people of Suntenjaya Village believe that ngukus is an important procession in praying to God. Technically, ngukus is an activity of whispering prayers along with the ijab kobul that has been described above to incense in the form of small grains that have been wrapped in a piece of paper and then stored on coals in a container. This is understood as an effort by the people of Suntenjaya Village so that the prayers they pray to their Lord can 
be immediately heard or answered. This is expressed by the following expression.

"Bul kukus buritan dana sira dadi sira sukma sukma nu ngukus sukma nu dikukusan Sri rasa Sri pangawasa sri hurip ku kersaning Allah. Astagpirulah haladim $7 x "$

(Bul steamed the stern of the fund so you are the soul, the soul that steams the soul that Sri Rasa Sri Pangawasa Sri hurip is aiming for by the will of Allah. Astagfirullahal'adzim 7x).

The expression bul or jebul 'appears' has the meaning of appearing you smoke from the combustion of energy sources through which our prayers can be delivered to our Lord, sira dadi sira sukma 'you are your soul' be, O prayers, please convey our prayers so that we can feel the results, sukma nu ngukus sukma nu dikukusan 'a soul with wheels and a soul that is prayed for' both for us as humans living on earth and for those who have left this world first, Sri rasa Sri pangawasa sri hurip ku kerkasing Allah ' Sri Rasa Sri Pangawasa Sri Hurip by Allah's will, all of which is aimed at Allah, the most gentle and the almighty.

In general, this procession is seen as a jampe or spell intended for supernatural beings. This is because someone who does the ngukus procession does not necessarily raise his voice so that the information obtained by listeners or the general public is not fully captured by them. In addition, the elders of Suntenjaya Village, who believe that this expression has the potential to be dangerous if it is not done or read incorrectly and not according to the time specified, make them read it in a whisper so that ordinary people do not arbitrarily and abuse the expression. In addition, ordinary people view the steaming activity, which they understand as an activity of whispering jampe or spell to incense, as a futile and misleading activity. However, this is not appropriate because they do so so that the prayers they have prayed can be heard by their Lord. This refers to the belief of the people of Suntenjaya Village who believe that there is an intermediary between themselves and their God.

\section{CONCLUSION}

Based on the explanation above, it can be concluded that there are three categories of verbal expression in the pilgrimage tradition of the Suntenjaya Village community, namely prayer, ijab kobul, and ngukus. In this case, the verbal expression in the pilgrimage tradition of the Suntenjaya Village community contains values that are upheld and preserved from generation to generation by their ancestors.

\section{REFERENCES}

- Abdullah, W. (2017). Kearifan Lokal dalam Bahasa dan Budaya Jawa: Studi Kasus Masyarakat Nelayan di Pesisir Selatan Kebumen Jawa Tengah (Kajian Etnolinguistik). Surakarta: UNS Press.

- Abdullah, W. (2015). Local Wisdom of the Fishermen's Language and Livelihood traditions in the Southern Coast of Kebumen, Central Java, Indonesia (An Ethnolinguistic Study), International Journal of Humanities and Social Science, 5(10), 138-145.

- Ahimsa-Putra, H. S. (2003). Etnosains mengungkap Pengetahuan Masyarakata Pedesaan, Dinamika pedesaan dan kawasan dan Kawasan, 4(4); 34-35.

- Chafidi, U. (2019). Verbal and Non-Verbal in Javanese Language of the Coastal Community in Banjar Kemuning Village, Sidoarjo, International Journal of Multicultural and Multireligious Understanding, 6(6), 185-194.

- Chapelle, C. A. (eds). (2013). The Encyclopedia of Applied Linguistics. Oxford: Wiley-Blackwell.

- Foley, W. A. (1997). Anthropological Linguistic an Introduction. University of Sydney: Blackwell Publisher.

- Garvin,, P. L. (eds). (1957). Cultural Anthropology and Linguistics, Report of the Seventh Round Table Meeting on Linguistics and Language Study. Washington DC: Georgetown University Press.

- Kridalaksana, H. (1982). Kamus Linguistik. Gramedia: Jakarta.

- Mardikantoro. (2016). Satuan Lingual Pengungkap kearifan Lokal dalam Pelestarian Lingkungan. Jurnal Bahasa, Sastra, Seni, dan Pengajarannya, 44(1), 47-59.

- Moleong, L. (2007). Metode penelitian kualitatif: Edisi Revisi. Bandung: PT Remaja Rosdakarya.

- Nurnaningsih (2019). Kearifan Lokal Bahasa Jawa dalam Tradisi Tingkeban di Kelurahan Laweyan Kotamadya Surakarta Sebuah Kajian Etnolinguistik, Kawruh: Journal of Language Education, Literature, and Local Culture, 1(1), 8195.

- Riley, P. (2007). Language, Culture, and Identity An Ethnolinguistic Perspective. New York: Continuum,

- Spradley, J. P. (2007). Metode Etnografi. Yogyakarta: Tiara Wacana.

- Subroto, E. (2007). Pengantar Metode Penelitian Linguistik Struktutral. Surakarta: UNS Press.

- Sudaryanto. (2015). Metode dan Aneka Teknik Analisis Bahasa: Pengantar Penelitian Wahana Kebudayaan Secara Linguistis. Yogyakarta: Sanata Dharma.

Cite This Article: Muhammad Rifqi Fauzan Arifin et al (2022). Verbal Expression in the Pilgrimage Tradition of the Suntenjaya Village Community. EAS J Humanit Cult Stud, 4(1), 15-21. 